\title{
PENDAMPINGAN REMAJA PUTRI TENTANG KESEHATAN REPRODUKSI DALAM MENGURANGI TINGKAT STRES PADA SAAT KEPUTIHAN DI PESANTREN ALMUQRI PARENDUAN
}

\author{
Dian Permatasari ${ }^{1}$,Emdat Suprayitno ${ }^{2}$ \\ 1Program Studi DIII Kebidanan Fakultas Ilmu Kesehatan Universitas Wiraraja \\ ${ }^{2}$ Program Studi Profesi Ners Fakultas Ilmu Kesehatan Universitas Wiraraja \\ E-mail: dianashadi118@gmail.com¹, emdat@wiraraja.ac.id²
}

\author{
Article History: \\ Received: 16-02-2021 \\ Revised: 19-02-2021 \\ Accepted: 21-02-2021 \\ Keywords: Vaginal \\ discharge; Reproduction \\ health; Youth
}

Kata Kunci: Keputihan; Kesehatan reproduksi; Remaja

\begin{abstract}
Absract: Leucorrhoea (fluorine Albus / vaginal discharge) is an excessive discharge of non-blood from the female genitals (vagina). Leucorrhoea is often considered normal by the community so that it is not handled properly, but this vaginal discharge could indicate disease. Physiological leucorrhoea is found in the condition before and after menstruation, sexual stimulation, pregnancy, ovulation, and emotional stress. The mentoring method used is to provide health education on reproductive health. The results of the implementation of health education were Al Muqri Parenduan Islamic boarding school students were active, enthusiastic in participating in activities, and active in discussing reproductive health. Activity participants can understand the level of stress on vaginal discharge and can explain again what has been conveyed.
\end{abstract}

\begin{abstract}
Abstrak: Keputihan (leukore/fluor albus/vaginal discharge) adalah keluarnya cairan bukan darah yang berlebihan dari kelamin perempuan (vagina). Keputihan sering dianggap biasa oleh masyarakat sehingga tidak ditangani dengan baik namun keputihan ini bisa saja menunjukan adanya suatu penyakit. Keputihan fisiologis dijumpai pada keadaan menjelang dan setelah menstruasi, mendapat rangsangan seksual, kehamilan, saat ovulasi dan stres emosional. Metode pendampingan yang dilakukan yaitu dengan memberikan edukasi Kesehatan tentang Kesehatan reproduksi. Hasil Pelaksanaan penyuluhan kesehatan yaitu siswi Pesantren Al Muqri Parenduan aktif, antusias mengikuti kegiatan dan aktif dalam berdiskusi tentang kesehatan reproduksi. Peserta kegiatan dapat mengerti tentang tingkat stres terhadap keputihan dan dapat menjelaskan kembali apa yang telah disampaikan.
\end{abstract}




\section{Pendahuluan}

Stres merupakan reaksi atau respon tubuh terhadap stresor psikososial, tekanan mental dan beban kehidupan. Stresor adalah berbagai hal yang dapat menyebabkan seseorang mengalami stres [1]. Bila seseorang dapat menanggapi stresor dengan baik maka keadaan individu akan senang namun jika stres tidak ditanggapi dengan baik maka individu akan mengalami depresi [2]. Stres juga dapat diartikan sebagai suatu kondisi yang disebabkan oleh adanya transaksi antara individu dengan lingkungannya yang mendorong seseorang untuk mempersepsikan adanya perbedaan antara tuntutan situasi dan sumber daya. [3].

Keputihan (leukore/fluor albus/vaginal discharge) adalah keluarnya cairan bukan darah yang berlebihan dari kelamin perempuan (vagina). Keputihan sering dianggap biasa oleh masyarakat sehingga tidak ditangani dengan baik namun keputihan ini bisa saja menunjukan adanya suatu penyakit [4]. Keputihan fisiologis dijumpai pada keadaan menjelang dan setelah menstruasi, mendapat rangsangan seksual, kehamilan, saat ovulasi dan stres emosional. Keputihan patologis karena infeksi yang tersering disebabkan oleh vaginosis bakterial, Trichomonas vaginalis dan Kandidiasis. [5].

Data penelitian tentang kesehatan reproduksi wanita menunjukan $75 \%$ wanita di dunia mengalami keputihan paling sedikit sekali seumur hidup dan 45\% diantaranya bisa mengalami dua kali atau lebih selama hidupnya [5]. Di Indonesia 70\% wanita mengalami keputihan paling sedikit satu kali seumur hidup. Angka ini berbeda jauh dengan eropa yang hanya $25 \%$ wanita pernah mengalami keputihan. Akibat yang dapat ditimbulkan dari keputihan ini antara lain adalah penyakit kehamilan ektopik, infertil dan juga merupakan salah satu gejala dari kanker serviks [6]

\section{Metode}

Rangkaian kegiatan yang dilakukan dalam Program Pengabdian pada sebagai berikut:

1. Sosialisasi

Sosialisasi tentang kegiatan ini dilakukan dan dimaksudkan untuk melihat kesiapan lokasi dan sasaran daerah kegiatan.

2. Penyusunan Materi

Materi pendidikan kesehatan di buat dalam dua bentuk yang pertama yaitu dalam bentul leaflet dan yang kedua dalam bentuk power point.

3. Penyiapan sarana dan prasarana Penyuluhan

Sarana dan prasarana yang pelu dipersiapkan pada kegiatan ini meliputi; perlengkapan dan Tata ruang/ lay out tempat penyuluhan.

4. Pelaksanaan Penyuluhan

Pada tahap ini tim akan diberikan pengetahuan tentang tugas-tugas untuk penyuluhan

\section{Hasil}

Hasil kegiatan penyuluhan kesehatan Reproduksi di Pusantren Al Muqri Parenduan diikuti oleh beberapa remaja di Pesantren Al Muqri Parenduan. Dari kegiatan yang 
telah dilakukan dalam bentuk pendidikan kesehatan terdapat beberapa hasil evaluasi kegiatan diantaranya

1. Evaluasi Struktur

Kepala pesantren, Staff dan beberapa petugas pesantren dapat bekerja sama dengan baik dan kooperatif dibuktikan dengan dalam persiapan kegiatan dengan ikut serta menyiapkan segala keperluan terkait penyuluhan yang di adakan di salah satu ruangan di Pesantren.

2. Evaluasi Proses

Pelaksanaan penyuluhan kesehatan terlihat aktif diikuti siswi Pesantren Al Muqri Parenduan bahkan mereka aktif dalam berdiskusi tentang kesehatan reproduksi. Peserta kegiatan dapat mengerti tentang tingkat stres terhadap keputihan dan dapat menjelaskan kembali apa yang telah disampaikan.

3. Evaluasi Hasil

Peserta kegiatan dapat mengerti dan memahami tentang adanya hubungan tingkat stres terhadap keputihan.

4. Keberlanjutan

Bagi peserta pentingnya meningkatkan pengetahuan tentang masalah reproduksi sangat membantu dalam menjaga kesehatan reproduksinya, karena masa remaja sangat berperan penting dalam kesehatan dirinya di masa depan

\section{Diskusi}

Dalam pengabdian ini, terdapat faktor pendorong atau pendukung dalam kegiatan pengabdian ini, diantaranya: Peran serta mitra dalam kegiatan Pengabdian Kepada Masyarakat cukup aktif di buktikan sejak awal sosialisasi, Kepala Pesantren dapat berjalan dengan lancar [7]. Kegiatan PKM di tempatkan di aula Pesantren Parenduan Sumenep dengan persiapan fasilitas kegiatan dapat di support langsung dengan dilakukan secara gotong royong. .Dalam Pelaksanaan PKM peran serta peserta/ siswi di Pesantren Al Muqri juga ikut terlibat dalam kelancaran acara ini, dimana pada saat penyuluhan renspon antusias mereka membuat acara berjalan dengan lancar. Selain faktor pendukung atau pendorang, terdapat pula faktor penghambat dalam kegiatan pengabdian ini, diantaranya adalah Peserta masih belum paham betul begitu pentingnya waktu, sehingga dari sebagian peserta masih ada yang terlambat datang pada saat sosialisa. Masih ada peserta yang Acuh Tak acuh ketika sosialisasi. Namun panitia langsung menegur dengan sopan peserta sehingga bisa di atasi [8] Berdasarkan hasil kegiatan penyuluhan kesehatan reproduksi tentang "Pengaruh Tingkat Stres terhadap Keputihan" berdampak baik khususnya bagi peserta/siswi dapat meningkatkan pengetahuannya.

\section{Kesimpulan}

Penyuluhan Kesehatan Reproduksi Tentang Tingkat Stres Terhadap Keputihan pada siswi Pesantren Al Muqri Parenduan berjalan dengan baik, sehingga berdasarkan evaluasi siswi sangat antusias mengikuti penyuluhan tersebut baik saat awal acara maupun sampai akhir acara. Kegiatan penyuluhan tersebut sangat baik untuk pengetahuan siswi terhadap pentingnya menjaga kesehatan reprosuksi. Di Pesantren hendaknya pengetahuan menjaga kesehatan khususnya kesehatan reproduksi lebih di 
tekankan lagi, agar tidak ada siswi yang masih kurang mengerti atau kurang paham tentang pentingnya menjaga kesehatan reproduksi karena di masa-masa remaja seperti merekalah pengetahuan umum ataupun mendalam sangat penting untuk masa kedepannya.

\section{Pengakuan/Acknowledgements}

Tidak lupa ucapan terimakasih pada pengasuh lembag ponpes al muqri yng berkenan memberikan waktu kepada kami uuntuknpenyukuhan hari in, dan tidak lupa pula bagi rekan rekan yang sudah membantu jalannya acara ini

\section{Daftar Referensi}

[1] E. Suprayitno, J. D. T. Purnomo, S. Sutikno, and R. Indriyani, "Health education in principle of community affected teenagaer's smooking attitude and habitual in the coastal area of madura island indonesia," Int. J. Psychosoc. Rehabil., vol. 24, no. 10, pp. 1492-1502, 2020, doi: 10.37200/IJPR/V24I10/PR300173.

[2] S. Y. S. Salat and E. Suprayitno, "Hubungan Kecemasan Ibu Menyusui Dengan Kelancaran Pengeluaran Air Susu Ibu (Asi ) Di Bps Kerta Timur Kecamatan Dasuk Kabupaten Sumenep. Relationship Between Mother's Anxiety Analysis With The swiftness of Breast Milk In BPS Kerta Timur Kecamatan Dasuk Kab,"vol. 5, no. 2, pp. 51-56, 2019, doi: https://doi.org/10.33023/jikeb.v5i2.479.

[3] P. S. Bobhate and S. R. Shrivastava, "A cross sectional study of knowledge and practices about reproductive health among female adolescents in an urban slum of Mumbai," 2011.

[4] H. ILMIAWATI, "Perilaku Personal Hygiene Pada Kasus Keputihan Remaja Putri di Lembaga Pendidikan Islam Nurul Haromain 'SMP Plus Fityani' Desa Ngroto Kecamatan Pujon Kabupaten Malang." UNIVERSITAS AIRLANGGA, 2016.

[5] E. Suprayitno, I. G. D. Pratiwi, and Z. Yasin, "Gambaran Penyebab Terjadinya Pembengkakan Payudara Pada Ibu Menyusui Di Polindes Desa Meddelen Kecamatan Lenteng," WIRARAJA Med., vol. 8, no. 1, pp. 13-18, 2018, doi: https://doi.org/10.24929/fik.v8i1.505.

[6] D. Permatasari and E. Suprayitno, "Implementasi Kegiatan Pendidik Sebaya dan Konselor Sebaya dalam Upaya Pencegahan Triad KRR di Pusat Informasi dan Konseling Remaja," J. Ners dan Kebidanan Uournal Ners Midwifery), vol. 7, no. 1, pp. 143-150, 2020.

[7] E. Surayitno and N. Huzaimah, "Pendampingan lansia dalam pencegahan komplikasi hipertensi," vol. 4, no. November, pp. 518-521, 2020.

[8] S. Suharto, F. P. Gurning, M. Y. Pratama, and E. Suprayitno, "Implementasi 
Kebijakan Penanggulangan HIV/AIDS di Puskesmas Teladan," J. Ris. Hesti Medan Akper Kesdam I/BB Medan, vol. 4, no. 2, pp. 131-136, 2020. 